\title{
İnformasiya iqtisadiyyatının kibertəhlükəsizliyinin təminatı istiqamətləri və texnologiyaları
}

\author{
Olövsat Đliyev \\ AMEA İnformasiya Texnologiyaları İnstitutu, Bakı, Azərbaycan \\ alovsat_qaraca@mail.ru
}

\begin{abstract}
Xülasə - Məqalədə İKT-yə əsaslanan yeni tipli iqtisadiyyatın formalaşma xüsusiyyətləri təhlil olunmuş vo iqtisadiyyatın inkişafına olan əsas risklər və təhlükələr göstərilmişdir. İqtisadi təhlükəsizlik səviyyəsini xarakterizə edən göstəricilər sistemi şərh edilmişdir. Yen iqtisadiyyatda informasiya infrastrukturu və texnologiyalarının vəzifələri müəyyənləşdirilmişdir. Rəqəmsal iqtisadiyyat sektorlarında informasiya təlükəsizliyi mənbələri vo baza texnologiyaları araşdırımışdır. İnformasiya iqtisadiyyatının kibertəhlükəsizliyi istiqamətləri və müvafiq texnologiyaları təklif edilmişdir.
\end{abstract}

Açar sözlor - informasiya iqtisadiyyat, iqtisadiyyatın informasiyalaşdırılması, iqtisadi tohlükosizlik səviyyosi, roqəomsal iqtisadiyyat, kibertohlükosizlik, tohlükasizlik texnologiyalart

\section{GİRIŞ}

İqtisadiyyatı daha çox inkişaf edən ölkələrin təcrübəsi göstərir ki, hazırda qlobal iqtisadi inkişaf innovativ texnologiyalara, biliklərə və informasiyaya əsaslanır. Hazırkı dövrdo iqtisadiyyatın davamlı inkişafına nail olmaq, sosialyönümlü, diversifikasiya olunmuş yeni milli iqtisadiyyatların formalaşdırılmasını həyata keçirmək aktual məsələlərindəndir. Makroiqtisadi sabitlik, regionların sürətli inkişafı, əlverişli biznes və investisiya mühiti əsasında tarazlı iqtisadi inkişaf modelini daha da təkmilləşdirmək tələb olunur. $\mathrm{Bu}$ tədbirlərin əsas məqsədi iqtisadi davamlılı̆̆ın və dayanıqlılığın gücləndirilməsi, müəssisələrin səmərəliliyinin artırılması yolu ilə iqtisadi dinamikliyin təmini, insan kapitalının inkişafı və biznes mühitinin daha da yaxşılaşdırılmasından ibarətdir. Burada əsas vasitə İKT-nin inkişaf potensialının artırılması, İKT infrastrukturunun təkmilləşdirilməsi, iqtisadiyyatın rəqəmsallaşdırılması, dövlət sektorunda İKT-nin tətbiqi ilə idarəetmənin səmərəliliyinin artırılması, innovasiyayönümlü, informasiya və biliyə əsaslanan iqtisadiyyatın qurulması, bazarlara rəqabətədavamlı İKT məhsullarının çıxarılması, yüksək texnologiyalara əsaslanan yeni investisiya layihələrinin ölkəyə cəlb edilməsidir [1].

İnformasiya və biliklərə əsaslanan cəmiyyətin qurulması, yüksək texnologiyalar parklarının yaradılması, elektron informasiya resurslarının inkişaf etdirilməsi, bank, maliyyə, ticarət, təhsil, tibb və s. sosia-iqtisadi sahələrdə elektron xidmətlərin daha geniş tətbiqi, regionlarda proqram vasitələrinin və texnoloji avadanlıqların istehsalının təşkili və inkişaf etdirilməsi formalaşmaqda olan informasiya iqtisadiyyatının əsas inkişaf istiqamətləridir. Ona görə də sosialyönümlü liberal bazar iqtisadiyyatına əsaslanan müasir informasiya və biliklər iqtisadiyyatı sektorlarının iqtisadi təhlükəsizliyinə ciddi ehtiyac yaranmışdır. $\mathrm{Bu}$ problemin kifayət qədər aktual xarakter daşıması həm 2020-ci ilə qədərki dövr üçün İnformasiya Cəmiyyətinin inkişafına dair Milli Strategiyada [2], həm də 2025 və daha sonrak1 dövrlər üçün milli iqtisadiyyat sektorlarının, xüsusilə telekommunikasiya və informasiya texnologiyalarının inkişafı üzrə strateji yol xəritələrində [3] təsbit olunmuşdur.

İnformasiya və biliklərə əsaslanan intellektual cəmiyyətin və iqtisadiyyatın təhlükəsiz və dayanıqlı formalaşdırılması dövlət və cəmiyyət qarşısında qoyulan əsas məqsədlərdəndir. Ona görə də yeni iqtisadiyyatda təhlükəsizlik məsələlərinin araşdırılması və çox mühüm əhəmiyyətli faktor kimi dəyərləndirilməsi kifayət qədər aktualdır.

\section{IKT-Yə ЭSASLANAN YENI TIPLİ İQTISADIYYATIN FORMALAŞMA XÜSUSIYYӘTLӘRI}

İqtisadiyyatın İKT əsasında inkişaf etdirilməsi müasir zamanın əsas tələblərindən biridir. Azərbaycanın öz iqtisadiyyatını Avropa iqtisadiyyatına inteqrasiya etdirməsi üçün iqtisadiyyatın informasiyalaşdırılması daha səmərəli və düzgün şəkildə həyata keçirilməlidir[4].

Sosial-iqtisadi vo digər sahələrin informasiyalaşdırılması istiqamətində [5] həm xidmət, ictimaisiyasi, humanitar sferalarda, həm də istehsal-sənaye, energetika, kənd təsərrüfatı və nəqliyyat sahələrində nisbətən mühüm potensial vardır. Xüsusilə, energetika sahəsinin, aqrar sektorun müasir İKT-dən istifadə əsasında inkişafı, nəqliyyat sahəsində yeni texnologiyaların tətbiqi həmin sahələrin effektiv idarə olunmasına əlavə imkanlar yaradır.

Bütün bu kimi real iqtisadi sahələrin və proseslərin səmərəli inkişafının kökündə İKT və cəmiyyətin kütləvi surətdə informasiyalaşdırılması dayanır. İqtisadiyyatın informasiyalaşdırılması və informasiya cəmiyyəti quruculuğu prosesi arasında sıx əlaqə mövcuddur və onlar bir-birinə ciddi qarşı1ıqlı təsir göstərən aktual məsələlərdir.

İKT-yə əsaslanan iqtisadiyyatın formalaşması konsepsiyası iqtisadiyyat elmində mövcud olan resursyönümlü iqtisadiyyat, ekoloji iqtisadiyyat, ətraf mühitin iqtisadiyyatı və 
s. kimi bir çox istiqamətlərin ideyalarını özündə birləşdirir. İKT əsaslı iqtisadiyyatda milli və beynəlxalq səviyyələrdə təbii resurslardan daha səmərəli istifadə olunur, yeni iş yerlərinin yaradılmasının hesabına əhalinin məşğulluğu daha səmərəli təmin olunur, davamlı inkişafin nailiyyəti üçün bazar mexanizmlərindən düzgün istifadə olunur. İKT əsaslı yeni iqtisadiyyat dayanıqlı inkişafa keçid prosesinin sürətlənməsinə yaxşı imkan yaradır.

İKT əsaslı iqtisadiyata keçidin zəruriliyi ondadır ki, insanın ətraf mühitə müsbət təsir imkanı daima genişlənir. İnsanın İKT vasitəsilə təsir imkanları artır. İKT bərpa olunmayan təbii ehtiyatların səmərəli inkişafına kömək edir.

Bəşəriyyət üzləşdiyi ekoloji, sosial və iqtisadi problemlərin həlli üçün İKT-yə əsaslanan yeni yanaşmalardan istifadə etməlidir. Ona görə də, hesab etmək olar ki, İKT-yə əsaslanan yeni əmək fəaliyyəti, yeni iqtisadiyyat, yeni istehsal, yeni təfəkkür və yeni həyat tərzi gələcək həyatımızın əsas komponentlərinə çevrilməlidir.

Hazırda dünyanın inkişaf tendensiyalarına müvafiq olaraq sənaye iqtisadiyyatı daha çox İKT və digər "yaşıl" texnologiyalar əsasında inkişaf etdirilir. Sənaye iqtisadiyyatının on böyük magistral inkişaf yolu elə informasiyalaşmadan, İKT-dən keçir.

İstehsalın vo idarəetmə proseslərinin informasiyalaşdırılması istiqamətində kifayət qədər inkişaf potensialı vardır. İqtisadiyyatın inkişafı tezisinə ilkin olaraq iqtisadiyyatın informasiyalaşdırılması konteksində baxmaq, informasiya iqtisadiyyatının innovativ üsullarla inkişaf etdirilməsi texnologiyalarının tətbiqinə nail olmaq olar. Bu isə nəticə etibarı ilə innovativ informasiya iqtisadiyyatı sektorlarının formalaşması və inkişaf etdirilməsidir.

Müasir dövrdə ənənəvi iqtisadi sahələrin informasiyalaşdırılması ilə yanaşı, elə sahələr də mövcuddur ki, orada inkişaf və informasiyalaşdırma üçün böyük potensial vardır. Belə sahələrə aşağıdakıları aid etmək olar[6]:

- enerji resurslarının səmərəli bölüşdürülməsi vasitəsilə qənaətedici texnologiyalar;

- iqtisadiyyatın bütün sahələrində yeni innovativ texnologiyaların yaradılması və tətbiqi vasitəsilə resurslardan səmərəli istifadə texnologiyaları;

- kənd təsərrüfatı sferasında İKT vasitəsilə işlərin səmərəli təşkili və resurslardan səmərəli istifadə texnologiyalari;

- tikinti sektorunda, nəqliyyatda, sənaye sahələrində, idarəetmə işlərində, resursların səmərəli yerləşdirilməsində İKT-nin tətbiqi;

- şəhər təsərrüfatının idarə olunmasında, bələdiyyələrin fəaliyyətinin təşkilində, mənzil fondunun istifadəsində İKT amilindən yararlanma;

- ekoloji sahədə, təbiətin mühafizəsində, geoloji axtarışlarda, turizm sahəsində İKT-nin imkanlarından istifadə və $\mathrm{s}$.

İnformasiyalaşdırma nəticəsində innovativ informasiya iqtisadiyyatı formalaşdıqca bir çox təhlükə yarada biləcək problemlər də meydana çıxır ki, onları müvafiq təhlükəsizlik texnologiyalarının işlənilməsi və tətbiqi hesabına aradan qaldırmaq və ya qarşısını almaq olar .

\section{III. İQTISADİ TəHLÜKəSIZLIK SəVIYYəSİ Və İQTISADIYYATDA ӘSAS TӘHLÜKӘLӘR}

Müasir qloballaşma və inteqrasiya proseslərinin sürətləndiyi, eləcə də, beynəlxalq rəqabətin daha da kəskinləşdiyi şəraitdə satış bazarları, texnoloji, informasiya, maliyyə, insan və təbiət resursları üzərində nəzarət sahəsində hər bir ölkənin milli və iqtisadi təhlükəsizliyi problemi daha da aktuallaşır və strateji xarakterə malik olur. Dünya iqtisadiyyatının böhranları fonunda hər bir dövlətin özünün milli maraqları mövcuddur ki, onları yalnız ölkənin iqtisadi təhlükəsizliyinin dayanıqlığı şəraitində qorumaq mümkündür. Dövlətin iqtisadi təhlükəsizlik səviyyəsi müəyyən keyfiyyət kriteriyaları və indikatorlarla xarakterizə olunur. $\mathrm{Bu}$ istiqamətdə C.Y.Qlazyev 22 əsas göstərici (istehsal dinamikası, milli büdcə, dövlət borcu və s.), V.K.Sençaqov isə 16 göstərici (azgəlirli əhalinin nisbəti, çoxgəlirli əhalinin nisbəti və s.) təklif etmişdir. İqtisadi təhlükəsizliyi, ümumilikdə, 150-dən çox göstərici xarakterizə edir. Bütün bunlarla yanaşı olaraq, [4]-də iqtisadi təhlükəsizliyi xarakterizə edən 18 əsas indikator verilmişdir. Onlardan 8-i makro xarakterli iqtisadi göstəricilər, 10-u isə orta və aşağ idarəetmə səviyyələrinə aid edilə bilən iqtisadi göstəricilər hesab oluna bilər.

Aparılan tədqiqatlar göstərir ki, [7, 8] milli iqtisadiyyatların əksəriyyəti üçün əsas təhlükələr sənaye istehsalının aşağı səviyyədə olması, ölkə iqtisadiyyatının məhsul idxalından və xammal ixracından asılılığı, əhalinin aşağı həyat səviyyəsi, kölgə iqtisadiyyatının inkişafı, korrupsiyanın artması, elmin, təhsilin, innovasiyanın inkişafdan qalması və ya zəif inkişafı, güclü beyin axınının olması və s. kimi çox ciddi problemlərdir.

\section{YENI İQTISADIYYATDA İNFORMASIYA İNFRASTRUKTURU VӘ TEXNOLOGIYALARININ ROLU VӘ VӘZIFӘLӘRI}

Әvvəlki bölmədə göstərilən təhlükələrin hamısının çox mühüm iqtisadi xarakterizo malik olması ilə yanaşı, qeyd olunmalıdır ki, milli iqtisadiyyatın iqtisadi təhlükəsizlik səviyyəsinin dayanıqlı təmini tamamilə və birbaşa olaraq onun informasiya təhlükəsizliyinin səviyyəsindən asılıdır [6, 9].

Yeni iqtisadiyyatın qarşısında ənənəvi sənaye iqtisadiyyatının vəzifələri ilə yanaşı yeni tələblər, məsələlər və məqsədlər qoyulmuşdur. Bunlar ölkə vətəndaşlarının maddi və mənəvi rifah halının, həyat keyfiyyətinin yaxşılaşdırılması üçün həm ənənəvi, həm də rəqəmsal formada olan məhsullara xidmətlə olan tələbatlarını daha dolğun və səmərəli şəkildə ödənilməsindən ibarətdir. $\mathrm{Bu}$ isə rəqəmsal texnologiyalardan 
daha geniş istifadə, əhalinin rəqəmsal savadlılı̆̆ının artırılması, insanların informasiya ilə təmin olunmaq səviyyəsinin yüksəlməsi, dövlət xidmətlərinə əlçatanlığın asanlaşması şəraitində mümkündür. Ona görə də hesab olunur $\mathrm{ki}$, formalaşmaqda olan müasir informasiya və bilik iqtisadiyyatı[10, 11] ancaq ən yüksək İKT infrastrukturu, kommunikasiya-rabitə vasitələri və kiber-fiziki sistemlərdən ibarət platformada effektiv fəaliyyət göstərə bilər. Belə platforma isə təhdid və təhlükələrdən qoruna bilən yüksək inkişaf etmiş informasiya təhlükəsizliyi sisteminə, etibarlı telekommunikasiya şəbəkəsinə, naqilsiz xətlərə, daimi monitorinq sistemlərinə, texniki tənzimləyici strukturlara, müvafiq yüksəkixtisaslı personala, yüksək səviyyədə təşkilati, hüquqi, maliyyə, normativ, ekoloji, sosial problemlərin operativ həllinə inkan verən mexanizmlərə malik olmalıdır.

Göründüyü kimi, burada əsas məsələ informasiya infrastrukturu və təhlükəsizliyinin səmərəli həllinə nail olmaqdir. $\mathrm{Bu}$ istiqamətdə ən qlobal texnologiyaların tətbiq olunması üçün yeni bilik və texnologiyaların müvafiq sahələrdə praktiki reallaşdırılması məqsədilə transferini həyata keçirən ixtisaslaşdırılmış texnomərkəzlər, texnopolislər, texnoparklar və s. yaradılmalıdır [12].

\section{INFORMASIYA İQTISADIYYATI SEKTORLARINDA INFORMASIYA TOLÜKOSIZLIYİ MONBOLORİ VӘ TEXNOLOGIYALARI}

İnformasiya iqtisadiyyatı sektorlarında tam informasiya təhlükəsizliyinin təmini üçün üç əsas - tamlıq, gizlilik və əlyetərlilik prinsiplərinə tamamilə əməl olunmalıdır [13].

Rəqəmsal iqtisadiyyat sektorlarında[14] informasiya resurslarının, sistemlərinin, məhsul və xidmətlərin informasiya təhlükəsizliyi daha çox aşağıdakı kimi risklərə, təhdid və təhlükələrə məruz qala bilər [15]:

- rəqəmsal mühitdə insanların özəl həyatının toxunulmazlığı, şəxsiyyət əleyhinə yönəlmiş təhdidlərin qarşısının alınması, şəxsi hüquqlarının təmini, şəxslərin identifikasiyası, onlara aid fərdi verilənlərin saxlanması və qorunması, onların inamının yüksəldilməsi

- şəxsiyyətə, biznesə, dövlətə ierarxik telekommunikasiya sistemlərindən və resurslarından uzaqdan istifadə zamanı yaranan təhlükə və təhdidlər;

- kritik informasiya infrastrukturuna xarici informasiyatexniki təsir inkanlarının artması;

- daxili və xarici kompüter cinayətkarlığı səviyyəsinin yüksəlməsi;

- aparıc1, güclü xarici dövlətlərdən İKT-nin inkişaf səviyyəsinə görə geridə qalmaq;

- sosial-iqtisadi inkişafin xarici dövlətlərin ixrac siyasətindən asılılı̆̆
- İKT-nin inkişafi və təhlükəsizliyi aspektində elmitədqiqat işlərinin nisbi zəifliyi, kifayət qədər yüksəkixtisaslı müvafiq personalın olmaması.

Göstərilən bu və ya digər təhlükəkərin zamanında qarşısının alınması üçün xüsusi aparat-texniki və proqram vasitələrinin işlənilməsi məqsədəuyğundur. Ancaq belə xüsusi texnologiyaların işlənilməsi çox çətin olduğundan və böyük maliyyə vəsaitləri tələb etdiyindən, heç olmasa, bütün iqtisadi sahələrdə istifadə oluna bilən standart, baza, universal texnologiyaların tətbiq olunması zəruridir [16].

Müvafiq iqtisadi informasiya texnologiyalarını aşağıdakı kimi qruplaşdırmaq olar:

- yüksək və çox yüksək məhsuldarlıqlı superkompüter texnologiyaları;

- kiber-fiziki sistemlərin, komplekslərin aparat-texniki vasitələrinin yaradılması texnologiyaları;

- kiber-bioloji insan-maşın sistemlərinin yaradılması texnologiyalari;

- verilənlərin sürətli yığımı, emalı, ötürülməsi üzrə kvant texnologiyalari;

- pilotsuz sistemlər və robototexniki texnologiyalar;

- Sənaye İnterneti və Oşyaların interneti texnologiyaları;

- iqtisadi-riyazi və imitasiya modelləşməsi, ehtiyatların və növbələrin idarə olunması texnologiyaları;

- neyroşəbəkə, genetik və digər koqnitiv texnologiyalar;

- duman-bulud hesablamaları texnologiyaları;

- boyük verilənlərin yığımı, emalı (Big-data) texnologiyalar1;

- virtual mühit və reallıq texnologiyalar1;

- paylanmış hesablamalar və verilənlər texnologiyaları;

- blokçeyn və digər maliyyə texnologiyaları;

- proqram mühəndisliyi texnologiyaları və s.; Aparılan təhlil və araşdırmalar göstərir ki, ümumiyyətcə formalaşmaqda olan informasiya iqtisadiyyatının və onun sektorlarının dinamik inkişafı üçün tətbiq olunan əsas qabaqcıl texnologiyalar sırasına böyük verilənlər, neyrotexnologiyalar və süni intellekt, blokçeyn texnologiyaları, kvant texnologiyaları, yeni istehsal, loqistik, satış, idarəetmə texnologiyaları, Sənaye İnterneti, robototexnika, sensor texnologiyaları, naqilsiz rabitə texnologiyaları, virtual reallıq texnologiyaları, soft-komputinq texnologiyaları, krptoqrafik texnologiyalar, mürəkkəb böyük hesablama texnologiyaları, bulud-duman texnologiyaları və s. kimilər daxildir [17]. Bu cür qabaqcıl texnologiyaların tətbiqi zamanı risk və təhlükələrin azaldılması istiqamətləri daha çox: a) şəxsiyyətin, cəmiyyətin, dövlətin daxili və xarici informasiya təhlükəsizliyinin müdafiəsinə, b) vətəndaşların ləyaqətli, keyfiyyətli yaşam tərzinə, c) ölkənin dayanıqlı 


\section{“Informasiya tohlükosizliyinin aktual multidissiplinar elmi-praktiki problemlori” IV respublika konfransı, 14 dekabr 2018-ci il}

sosial-iqtisadi inkişafına və suverənliyinə yönləndirilmişdir. $\mathrm{Bu}$ kompleks istiqamətləri aşağıdakı kimi tədbirlərin yerinə yetirilməsiylə ifadə etmək olar:

- verilənlərin emalı mərkəzləri infrastrukturunun və aparat vasitələrinin fəaliyyətinin təhlükəsizliyinin və texnoloji müstəqilliyinin təmini;

- İnternet şəbəkəsinin ölkə seqmentinin təhlükəsiz fəaliyyətinin təmini;

- yeni iqtisadi şəraitdə kiber-fiziki sistemlərin fəaliyyət mexanizmlərinin işlənilməsi və onların təhlükəsiz icrasının təmini;

- kiber-fiziki sistemlərin fəaliyyəti üçün inam mühitinin formalaşdırılması üçün zəruri əsasların yaradılması;

- müxtəlif səviyyəli və təyinatlı informasiya sistemlərinin və texnologiyalarının təhlükəsizliyinin və dayanıqlılığının təmini;

- yeni iqtisadi şəraitdə informasiya təhlükəsizliyi üzrə beynəlxalq qarşılıqlı əlaqələrin təmini;

- beynəlxalq iqtisadi informasiya fəzaları ilə inteqrasiya olunan informasiya resurslarının, sistemlərinin təhlükəsizliyinin təmini və $\mathrm{s}$.

Göstərilən tədbirlər informasiya təhlükəsizliyi sistemlərinin, interfeyslərinin, elementlərarası qarşılıqlı əlaqə protokollarının, aparat vasitələrinin yeni idarəetmə konsepsiyasının işlənilməsini tələb edir [18].

Bunlarla yanaşı bir sıra informasiya təhlükəsizliyi texnologiyaları da qeyd edilən məqsəd üçün çox əhəmiyyətlidir [19]:

- kiberfəzaya nəzarət, kompüter hücumlarının qarşısının əvvəldən alınmasına xidmət edən koqnitiv texnologiyalar;

- rəqiblərin vəziyyətinin avtomatlaşdırılmış modelləşdirilməsi və proqnozlaşdırılması texnologiyalari;

- big data əsaslı proseslərin informasiya təhlükəsizliyi təminatının intellektual texnologiyaları;

- təhlükəsizliyin arxitektur-adaptiv texnologiyaları;

- proqram konfiqurasiyalı şəbəkə və şəbəkə funksiyalarının virtuallaşması texnologiyaları;

- kriptoqrafik modullar texnologiyalari;

- sənaye və Oşyaların İnternetinin təhlükəsizliyi texnologiyaları;

- təhlükəsiz bulud-duman və mobil texnologiyaları.

\section{NӘTїə}

Beləliklə yekunda qeyd olunmalıdır ki, ölkə iqtisadiyyatının informasiya təhlükəsizliyinə yalnız sistemli yanaşma əsasında nail olmaq olar. Burada həm qanunvericilik aspektində inzibati mexanizmlərdən, həm effektiv təşkilati tədbirlərdən, həm də müvafiq müasir aparat-texniki vasitə və texnologiyalardan kompleks şəkildə istifadə olunmalıdır.

\section{ӘDӘВIYYAT}

[1] Azərbaycan - 2020: Gələcəyə Baxiş” İnkişaf Konsepsiyası. Bakı, 29 dekabr 2012-ci il. www.president.az

[2] Azərbaycan Respublikasında İnformasiya Cəmiyyətinin İnkişafina dair 2014-2020-ci illər üçün Milli Strategiya. 02.04.2014-cü il, www.president.az

[3] Milli iqtisadiyyat və iqtisadiyyatın əsas sektorları üzrə Strateji Yol Xəritələri. Bak1, 6 dekabr 2016-cı il. www.president.az

[4] Алиев А.Г. Проблемы информатизации общества и экономики // Баку, “ЭЛМ”, 2003, 460 с

[5] Алиев А.Г. Теоретико-прикладные аспекты информатизации гуманитарных отраслей // Баку, “ЭЛМ”, 2006 г., 474 с.

[6] Э.Q.Đliyev, E.H.Musayeva, V.Ө.Abbasova, L.Ә.Đkbərova, İqtisadiyyatın informasiyalașdırılmasının bəzi təhlükəsizlik aspektlər // “İnformasiya təhlükəsizliyinin multidissiplinar problemləri” üzrə II respublika elmi-praktiki konfransı. Bakı, 14may, 2015, səh.148-149

[7] Григорьева В.В., Струков Г.Н., Слепокурова Ю.И., Слепокурова А.А. Экономическая безопасность Российской Федерации: современное состояние, уровень и угрозы. Вестник ВГУИТ. 2017. Т. 79. №3. Стр.238-252

[8] Ясенев В.Н. Информационная безопасность в экономических системах. Н. Новгород, 2006, 253 стр.

[9] Oliyev Ә.Q. İnformasiya sistemlərinin təhlükəsizliyinə vurulan ziyanların kompleks qiymətləndirilməsi məsələləri. "İnformasiya təhlükəsizliyi problemləri” I Respublika elmi-praktiki konfransı. Bak1, 16-17 may 2013, səh.71-74

[10] Alguliyev R.M., Aliyev A.G., Abbasova V.A. The study of formation characteristics and development tendencies of international information and knowledge economy. J. Review of knowledge economy. 2017, vol.4, No.1, pp.7-14. http://www.conscientiabeam. com/archive/67/06-2017/1

[11] Aliyev A.G. Methodological aspects of estimation of ICT-based economic development. International Journal Management Dynamics in the Knowledge Economy. 2018, vol.6 no.2, pp.227-245

[12] Oliyev O.Q., Şahverdiyeva R.O. İnnovativ struktur və proseslərin idarə olunmasında informasiya təhlükəsizliyi məsələləri. “İnformasiya təhlükəsizliyinin multidissiplinar problemləri" üzrə II respublika elmi-praktiki konfransı. Bak1, 14 may, 2015, səh.66-69

[13]Boban, Marija. Information security and the right to privacy in digital economy- the case of republic of Croatia Conference: 37 th International Convention on Information and Communication Technology, Electronics and Microelectronics (MIPRO).Croatia, may 26-30, 2014, pp.1503-1508

[14]Цифровая экономика: основные направления развития. Монография / Под научной редакцией Н.В. Апатовой Симферополь, 2018

[15] Vinze Ajay S., Raghu T. Information security in the knowledge economy. Int. J. Human-Computer Studies 65 (2007) pp.1-2

[16]Минзов А.С., Невский А.Ю., Баранов О.Ю. Информационная безопасность в цифровой экономике. Ж., ИТНОУ, 2018, №3, стр.52-59

[17]Мамаева Л.Н. Характерные проблемы информационной безопасности в современной экономике. Научно-практический журнал «Информационная безопасность регионов». 2016. № 1(22), стр.21-24

[18]Светлаков А. Г., Глотина И. М. Влияние информационного пространства на экономическую безопасность региона // Экономика региона. - 2018. - Т. 14, вып. 2, с. 474-484 
[19]Петренко С.А. Вызовы и угрозы безопасности цифровой экономики Российской Федерации. Финансово-экономическое и информационное обеспечение инновационного развития региона. Сборник материалов Всероссийской научнопрактической конференции. 2018, стр.74-77

\title{
CYBERSECURITY TECHNOLOGIES AND \\ DIRECTION IN THE INFORMATION ECONOMY
}

Alovsat G.Aliyev

Institute of Information Technology of ANAS,

Baku, Azerbaijan

alovsat_qaraca@mail.ru

\begin{abstract}
In the article, the features of the new type of economy based on ICT have been analyzed .The main risks and threats on the development of the economy are shown. The system of indicators describing the level of economic security has been commented. The tasks of information infrastructure and technology have been defined in the new economy. Sources of information security and basic technologies have been researched in the digital economics sectors. Relevant technologies have been proposed for cyber security in the information economy.
\end{abstract}

Keywords - information economy, informatization of economy, economic security, digital economy, cyber security, security technologies 